\title{
Company Managers' Knowledge and Skills in the Use of Data Analytics in Decision-Making Process: Basis for Developing Program
}

\author{
Maricar V. Maniquis \\ School of Graduate Studies, Laguna College of Business and Arts \\ DOI: 10.29322/IJSRP.11.08.2021.p11614 \\ http://dx.doi.org/10.29322/IJSRP.11.08.2021.p11614
}

\begin{abstract}
The main thrust of this study was to determine the level of knowledge and skills in the use of data analytics in the decision-making process performed by Company Managers as assessed by the employees specifically in the areas of forecasting and planning, employee learning and development, setting-up of key performance indicators, and process improvement. The development program to improve the data knowledge and skills of the Employees and Company Managers to support a better decision-making process was the output of the study. This study followed the quantitative descriptive correlational research design. Through random sampling, the respondents of the study were 104 employees and used the company's business systems applications. A validated researcher-made survey instrument created via Google survey was used for the gathering of data. For statistical treatment, simple mean, four-point Likert scale and the Pearson Product-Moment Correlation Coefficient were used.

As the results revealed, the strength of the association between knowledge and skills of the Company Managers in using data analytics in the decision-making process is high. This reveals that familiarity with the theoretical concepts about data can manifest in the ability to apply them in the workplace. Based on the finding of the study, it can also be concluded that a development program is essential to enhance the level of knowledge and skills of Company Managers in the use of data analytics in their decision-making process.
\end{abstract}

Index Terms- company managers' knowledge, skills, data analytics, decision-making process

\section{INTRODUCTION}

A ccording to a recent study conducted by International Data Corporation (IDC) in November 2018, the Global Datasphere is experiencing tremendous growth, and IDC predicts that it will grow from 45 Zettabytes (ZB) in 2019 to 175ZB in 2025 - equivalent to $17.5 \mathrm{bn}$ hard drives with one terabyte of capacity each. It means that every person, activity, and device has become a data point.

In a recent survey conducted by PwC, the 2020 PwC Data Analytics Assessment Readiness Survey, two out of five companies are highly data-driven while the rest are somewhat or rarely data-driven. Organizations also mostly use descriptive and diagnostic analysis, which focuses more on hindsight rather than foresight. Most Philippine companies have already started or planning to embed data analytics in their daily operations, with three out of five having data analytics teams. The result of the overall survey showed an average of $40 \%$ of companies relies on data, which means most companies still make decisions based on intuition.

Tan (2017) mentioned that the rise of digitization has fueled an urgency for our business decision makers in the Philippines to rapidly adopt data analytics as they are becoming aware of the importance of data. According to Ernst and Young (EY) and Forbes Insights, in today's widespread business disruption, the stakes are higher than ever. To maximize the value of data analytics, companies are embedding it into all parts of their enterprises, beyond the traditional pockets such as marketing and sales departments.

This study aims to explore the level of knowledge and skills in the use of data analytics in the decision-making process performed by Company Managers as assessed by the employees. These employees are the individuals who have access to the companies' business systems applications who belongs to various industries such as Real Estate, Service, Communications, Investment, and Manufacturing Industries engaged in Consumer, Fabrication, and Electronics located in the National Capital Region, Cavite, Batangas, and Laguna. Moreover, this study has pursued to provide an enhancement development program to improve the knowledge and skills of Company Managers in the use of data analytics in the decision-making process. 


\section{IDENTIFY, RESEARCH AND COLLECT IDEA}

The study aims to explore the level of knowledge and skills in the use of data analytics in the decision-making process performed by Company Managers as assessed by the employees.

Specifically, the research seeks to answer the following questions:

1. What is the level of knowledge of company managers in the use of data analytics in decision-making process as assessed by the employees when it comes to areas of:

1.1. forecasting and planning,

1.2. employee learning and development,

1.3. setting up of key performance indicators and

1.4. process improvement?

2. What is the level of skills of Company Managers in the use of data analytics in the decision-making process as assessed by the employees in the areas of:

2.1. forecasting and planning,

2.2. employee learning and development,

2.3. setting up of key performance indicators, and

2.4. process improvement?

3. Is there any significant relationship between the level of knowledge and skills in the use of data analytics in the decisionmaking process of Company Managers?

4. What development program can be proposed to improve the knowledge and skills of Company Managers in the use of data analytics in the decision-making process?

\section{Related Literature}

In today's fast-paced and complex business world, leaders continuously refine their decision-making process practices to ensure that they are on the right path. Onley (2019), Malhorata (2018), and Wishart (2018) all agree on four commonly recognized decisionmaking styles which are directive, conceptual, analytical, and behavioral. Meanwhile, the studies conducted by Hallo, Nguyen, Gorod, and Tan (2020) and Jackson, Kleitman, Howie, and Stankov (2016) concluded that the human aspect such as heuristics and biases impacts the effectiveness of decision-making.

The use of data analytics in the decision-making process is widely embraced and used by companies worldwide. Both Delen (2019) and Roy (2017) agree that organizations use commonly used types of data analytics that help improves their decision-making process, these are descriptive, diagnostic, predictive, and prescriptive. Durcevic (2019), Marr (2017), Kaluba (2020), Alcala (2017), Stobierski (2019), Shacklett (2020, and Wassmer (2020) all stated that data should be at the core of any decision-making process and that every leader should consider having a data strategy in place and consider this as a roadmap for ensuring that the right data is in the right place, at the right time and that the reasons for poor decision making is the lack of data strategy and poor data quality and business data practices and that making decisions based on data analysis should be considered a step in the right direction of a larger objective or goal. Both Swabey (2018) and Vigliarolo (2020) stated that the use of data in decision-making is linked to good performance, however there are also serious problems when it comes to data literacy - understanding of how to use data analysis as one of the greatest challenges organization faces in using data to support decision-making and that while businesses understand the value of data, employees aren't being trained to use it.

The ability to understand and communicate about data is an increasingly important skill as stated by Bowne-Anderson (2018), Turnali (2017) and Zettelmeyer (2015), they stated that decision-makers need to use data to support and strengthen their arguments, not arguments to support and justify data. Gottlieb and Weinburg (2019), and Schlenker (2020) said that high-performing organizations are making data a core part of employees' workflows and mindsets by educating them as part of a broader effort to build a strong datadriven culture and Company Managers should develop their analytical skills and consequently their value to their business need to understand digital technologies influence organizational skills, processes, and networks. Castor (2020) and Schlenker (2020) said that business leaders mistakenly attribute their poor performance to failure in the data science department and the end goal of Data Science isn't to introduce artificial intelligence, but to improve how people make decisions.

Meanwhile, Pelland (2017), Gilliland (2020), Chase (2019), and Scuoler (2020) all agreed that that business forecasting and predictive analytics are merging to leverage Big Data as a growth driver. Chandran (2019), Cook (2017), and Omer (2019) stated that an organization needs analytics to know if the company's learning and development program is making a difference and that learning analytics offer decision-makers deeper insights into how corporate training programs are aligned with organizational goals and individual learning needs. Durcevic (2020), Kohl (2019), and Malhorata (2019) mentioned that by collecting the right data, visualizing, taking advantage of real-time updates, and sharing insights with relevant stakeholders, each member of the team has the opportunity to outperform their goals, immediately act on inefficiencies, and establish a positive, data-driven culture that will benefit the company as a whole and all is founded on a data-driven culture. Marr (2017), Solanki (2018), Ismail (2017), and Peco (2018) all agreed that data plays a hugely important role in modern business processes and it can make companies more efficient, productive, and even help predict future market trends as well data governance sits at the core of long-term, sustainable success. 


\section{Research Design}

The sampling composed of one hundred four (104) randomly selected employees, thru the help of the Company Managers, a Google Survey link was provided via email and messenger so they can participate in the quantitative data collection of the study. The sample size resulted from the use of the G*Power tool as coordinated with the LCBA Statistician.

\section{Respondents of the Study}

The respondents of the study were the employees who come from various industries such as Real Estate, Service, Communications, Investment, and Manufacturing Industries engaged in Fabrication, Consumer, and Electronics located in the National Capital Region, Cavite, Batangas, and Laguna. These employees are those individuals employed in the company that has an access and uses the company's business systems applications.

Table A

Distribution of Respondents According to Type of Industry

\begin{tabular}{cccc}
\hline No. & Type of Industry & $\begin{array}{c}\text { Sample } \\
\text { Respondents }\end{array}$ & Percentage \\
\hline 1 & Real Estate & 2 & $1.92 \%$ \\
2 & Communications & 16 & $15.38 \%$ \\
3 & Service & 21 & $20.19 \%$ \\
4 & Investment & 2 & $1.92 \%$ \\
5 & Manufacturing & 63 & $60.58 \%$ \\
& Total & $\mathbf{1 0 4}$ & $\mathbf{1 0 0 \%}$ \\
\hline
\end{tabular}

As shown above, there was a total of one hundred four (104) respondents who came from various industries such as Real Estate, Communications, Service, Investment, and Manufacturing.

\section{Research Instrument}

The study has utilized a researcher-made online structured survey questionnaire specifically a Google Survey questionnaire as an instrument of the study. It consisted of two parts that have assessed the level of knowledge and skills in the use of data analytics in the decision-making process of the Company Manager specifically in the areas of planning and forecasting, employee learning and development, the setting up of key performance indicators, and process improvement.

The scale that follows contain the categorical responses and verbal interpretation used for the survey instrument.

$\begin{array}{llll}\text { Scale } & \text { Range } & \text { Categorical Response } & \text { Verbal Interpretation }\end{array}$

\begin{tabular}{cccc}
\hline 4 & $3.25-4.00$ & Strongly Agree & Very High \\
3 & $2.50-3.24$ & Agree & High \\
2 & $1.75-2.49$ & Disagree & Low \\
1 & $1.00-1.74$ & Strongly Disagree & Very Low \\
\hline
\end{tabular}

\section{Data Gathering Procedure}

A formal letter of request was sent via email to the target companies' Company Managers and Heads to seek approval in conducting the study. Upon approval, the survey was shared by the Company Managers and Heads to their respective colleagues and staff. The online survey was conducted from April 19 - May 7, 2021. The data was gathered using the online Google survey tool. The results were analyzed with the help of a Statistician using SPSS.

\section{Treatment of Quantitative Data}

The following were the statistical treatments applied to answer the problems related to the study:

1. For the level of knowledge and skills in using data analytics in the decision-making process of the Company Managers as assessed by the Employees, the Likert scale was utilized to obtain the responses. The four (4) point scale is ranging from four (4) being the highest and one (1) being the lowest. The four (4) point Likert scale will force the respondent to form an opinion, eliminating any safe 'neutral' option, thus ensuring the achievement of the objectives of the study. Results were analyzed using SPSS. Simple mean was applied. 
2. For the relationship between the level of knowledge and skills in using data analytics in the decision-making process of Company Managers, the Pearson Product-Moment Correlation Coefficient was used.

\section{WRITE DOWN YOUR STUDIES AND FINDINGS}

Problem Number 1 . What is the level of knowledge of company managers in the use of data analytics in decision-making process as assessed by the employees?

\subsection{Forecasting and Planning}

Table 1.1 shows the Level of Knowledge of Company Managers in the use of data analytics in the Decision-Making Process as assessed by the Employees in terms of Forecasting and Planning. The general assessment was 3.15, which was verbally interpreted as "HIGH". The indicator "My manager relies on data in the preparation of our annual budget" has the highest computed mean of 3.37, which was verbally interpreted as Very High, while the indicator "My manager is updated with the current technology trends about data science" has the least computed mean of 2.92 and was verbally interpreted as High.

Table 1.1

Level of Knowledge of Company Managers in the Use of Data Analytics in Decision-Making Process in terms of Forecasting and Planning

\begin{tabular}{lcc}
\hline My manager... & $\overline{\boldsymbol{X}}$ & VI \\
\hline Completed a formal training related to data analytics. & 3.04 & High \\
Always asks me to generate reports from our business application & 3.02 & High \\
system. & 3.37 & Very High \\
Relies on data in the preparation of our annual budget. & 3.21 & High \\
Relies on data when it comes to planning resources (hiring, & 3.33 & Very High \\
promotion). & 3.17 & High \\
Encourages me to use data in my daily work. & 2.92 & High \\
Reviews and checks my use of data in my daily work. & $\mathbf{3 . 1 5}$ & HIGH \\
\hline Is updated with the current technology trends about data science. &
\end{tabular}

Legend: 3.25 - 4.00 Very High, 1.75 - 2.49 Low, 2.5 - 3.24 High, 1.00 - 1.74 Very Low

It can be concluded that Company Managers have a high level of Knowledge in Forecasting and Planning in the use of data analytics in the Decision-Making Process. They got the highest computed mean on using data in the preparation of their annual budget. This makes the most sense as this is the season where Company Managers rely heavily on historical data from their business systems applications. However, being updated with the current technology trends about data science got the lowest mean which explains why the assessment on Company Managers having completed formal training related to data analytics also got a low computed mean.

As stated by Marr (2017), company managers should source and analyze the right data to provide insights that helps them answer questions such as "how can we target this customer segment?" or "how can we increase turn-over by 10\%?". Delen (2019) also supported this stating that organizations commonly apply analytics to large collections of data to describe, predict, and prescribe for improving business performance. All of these are factors in the preparation of the company's annual budget. Furthermore, Pelland (2017) said the corporate forecasting is shifting its emphasis from relying primarily on past data to influence future plans toward applying advanced analytics to help improve business and financial performance by understanding their data, customers, markets and organizations completely.

\subsection{Employee Learning and Development}

Table 1.2

Level of Knowledge of Company Managers in the Use of Data Analytics in Decision-Making Process in terms of Employee Learning and Development

\begin{tabular}{lcc}
\hline My manager... & $\overline{\boldsymbol{X}}$ & VI \\
\hline Relies on data when it comes to assessing my learning journey. & 3.13 & High \\
$\begin{array}{l}\text { Always asks me to generate reports from our business application } \\
\text { system. }\end{array}$ & 3.05 & High \\
$\begin{array}{l}\text { Relies on data when it comes to assessing my development and } \\
\text { training needs. }\end{array}$ & 3.15 & High \\
$\begin{array}{l}\text { Encourages me to use data when it comes to assessing my own } \\
\text { learning journey. }\end{array}$ & 3.12 & High
\end{tabular}


Encourages me to use data when it comes to assessing my own development and training needs.

Monitors my learning and development plan using data analytic tools.
3.10 High

$3.06 \quad$ High

\begin{tabular}{ccc}
\hline GENERAL ASSESSMENT & $\mathbf{3 . 1 0}$ & HIGH \\
\hline Legend: $3.25-4.00$ Very High, $1.75-2.49$ Low, $25-3.24$ High, $1.00-1.74$ Very Low &
\end{tabular}

Table 1.2 shows the Level of Knowledge of Company Managers in the use of data analytics in the Decision-Making Process as assessed by the Employees in terms of Employee Learning and Development. The general assessment was 3.10, which was verbally interpreted as "HIGH".

The indicator "Relies on data when it comes to assessing my development and training needs" has the highest computed mean of 3.15, which was verbally interpreted as High, while the indicator "Always asks me to generate reports from our business application system" has the least computed mean of 3.05 and was verbally interpreted as High.

In review, the result showed that Company Managers have a high level of Knowledge in Employee Learning and Development in the use of data analytics in the Decision-Making Process. The results imply that they have a high level of knowledge at relying on data when it comes to assessing the development training needs of their employees. Meanwhile, the indicator regarding Company Managers asking their staffs to always generate reports from their business application system got the lowest mean was likely affected by the ability to monitor their learning and development plan using data analytic tools which got a low computed mean as well.

This is supported by Cook (2017) stating that performance is strongly tied to learning and development, but, without analytics, it's difficult to tell how exactly learning affects employee performance. Chandran (2019) also shared the same sentiment saying that the single biggest challenge faced by learning organizations and learning leaders is to evaluate the effectiveness of their learning interventions.

According to Chandran (2019) Learning \& Development (L\&D) professionals understand that learning is crucial to business performance but proving the value of $L \& D$ to other parts of the organization, including business leaders and decision makers, is an uphill task. Why do Chief Learning Officers (CLOs) and their teams struggle in this area? Chandran (2019) said that the answer lies in the practical challenges they face in measuring the effectiveness of learning programs, and hence, the challenge in showing impact to business imperatives or performance.

\subsection{Setting Up of Key Performance Indicators}

Table 1.3

Level of Knowledge of Company Managers in the Use of Data Analytics in Decision-Making Process in terms of Setting Up of Key Performance Indicators

\begin{tabular}{|c|c|c|}
\hline My manager.. & $\overline{\bar{X}}$ & VI \\
\hline $\begin{array}{l}\text { Sees to it that all pertinent data in setting up KPI are available in our } \\
\text { system. }\end{array}$ & 3.36 & Very High \\
\hline $\begin{array}{l}\text { Always asks me to generate reports from our business application } \\
\text { system. }\end{array}$ & 3.17 & High \\
\hline Relies on data when it comes to setting up the team's KPI. & 3.39 & Very High \\
\hline $\begin{array}{l}\text { Encourages me to use data when it comes to planning my individual } \\
\text { KPI. }\end{array}$ & 3.41 & Very High \\
\hline $\begin{array}{l}\text { Provides inputs on how to use data analytics in planning my } \\
\text { individual KPI. }\end{array}$ & 3.35 & Very High \\
\hline $\begin{array}{l}\text { Relies on data to evaluate operational metrics for her team's } \\
\text { performance indicator. }\end{array}$ & 3.37 & Very High \\
\hline GENERAL ASSESSMENT & $\mathbf{3 . 3 4}$ & $\begin{array}{l}\text { VERY } \\
\text { HIGH }\end{array}$ \\
\hline
\end{tabular}

Legend: 3.25 - 4.00 Very High, 1.75 - 2.49 Low, 2.5 - 3.24 High, $1.00-1.74$ Very Low

Table 1.3 shows the Level of Knowledge of Company Managers in the use of data analytics in the Decision-Making Process as assessed by the Employees in terms of Setting Up of Key Performance Indicators. The general assessment was 3.34, which was verbally interpreted as "VERY HIGH".

The indicator "Encourages me to use data when it comes to planning my individual KPI" has the highest computed mean of 3.41, which was verbally interpreted as Very High, while the indicator "Always asks me to generate reports from our business application system" has the least computed mean of 3.17 and was verbally interpreted as High.

To conclude, Company Managers have a very high level of Knowledge in Setting Up Key Performance Indicators in the use of data analytics in the Decision-Making Process. They got a very high level of knowledge when it comes to encouraging their staffs to use data when it comes to planning their individual KPI, which directly relates why they also got a very high computed mean when relying on data when it comes to setting up their team's KPI. However, Company Managers got the lowest mean when it comes to asking their staff to generate reports from their business application systems. 
Kohl (2019) said that KPIs should be refined and standardized as early in the development process as possible and that comes from a full buy-in from the executive team and all leaders within the organization. All of this according to Kohl (2019) is founded on a data-driven culture.

Moreover, Durcevic (2020) said that by establishing clear operational metrics and evaluate performance, companies have the advantage of using what is crucial to stay competitive in the market, and that's data. Durcevic (2020) also deduced that by collecting the right data, visualizing, taking advantage of real-time updates, and sharing insights with relevant stakeholders, each member of the team has the opportunity to outperform their goals, immediately act on inefficiencies, and establish a positive, data-driven culture that will benefit the company as a whole.

\subsection{Process Improvement}

Table 1.4 shows the Level of Knowledge of Company Managers in the use of data analytics in the Decision-Making Process as assessed by the Employees in terms of Process Improvement. The general assessment was 3.35, which was verbally interpreted as "VERY HIGH". The indicator "Sees to it that all pertinent data to improve the department's processes are available in our system" has the highest computed mean of 3.40, which was verbally interpreted as Very High, while the indicator "Relies on data to improve her department's processes" has the least computed mean of 3.31 and was verbally interpreted as Very High.

Table 1.4

Level of Knowledge of Company Managers in the Use of Data Analytics in Decision-Making Process in terms of Process Improvement

\begin{tabular}{|c|c|c|}
\hline My manager... & $\overline{\boldsymbol{X}}$ & VI \\
\hline $\begin{array}{l}\text { Sees to it that all pertinent data to improve the department's } \\
\text { processes are available in our system. }\end{array}$ & 3.40 & Very High \\
\hline Relies on data analytics to assess process gaps in our department. & 3.33 & Very High \\
\hline $\begin{array}{l}\text { Promotes the use of data when it comes to evaluating any process } \\
\text { improvement in our department. }\end{array}$ & 3.32 & Very High \\
\hline $\begin{array}{l}\text { Provides inputs on how to use data to analyze any process } \\
\text { improvement in our department. }\end{array}$ & 3.37 & Very High \\
\hline Relies on data to optimize her department's processes. & 3.36 & Very High \\
\hline Relies on data to improve her department's processes. & 3.31 & Very High \\
\hline GENERAL ASSESSMENT & 3.35 & $\begin{array}{l}\text { VERY } \\
\text { HIGH }\end{array}$ \\
\hline
\end{tabular}

Legend: 3.25 - 4.00 Very High, 1.75 - 2.49 Low, 2.5 - 3.24 High, 1.00 - 1.74 Very Low

In summary, Company Managers have a very high level of Knowledge in Process Improvement in the use of data analytics in the Decision-Making Process. All indicators under this variable got a very high result and it was evident that they have a very high level of knowledge in ensuring that all pertinent data to improve the department's processes are available in their system and every improvement and optimization done in their business processes are all data-driven.

According to Ismail (2017), gathering data from your business processes and analyzing it can start to unearth some surprising insights. You can then use these insights to create process improvements, increase efficiency, reduce waste, and enhance profits. Additionally, Solanki (2018) stated that data is now more accessible than ever and to improve efficiency in business processes, every organization collects related information.

Problem Number 2. What is the level of skills of company managers in the use of data analytics in decision-making process as assessed by the employees?

The tables that follow provide findings on the problem stated above.

\subsection{Forecasting and Planning}

Table 2.1

Level of Skills of Company Managers in the Use of Data Analytics in Decision-Making Process in terms of Forecasting and Planning

\begin{tabular}{lcc}
\hline My manager... & $\overline{\boldsymbol{X}}$ & VI \\
\hline Uses data in the preparation of annual budget. & 3.41 & Very High \\
Uses data when it comes to planning resources (hiring, promotion). & 3.37 & Very High \\
Teaches me on how to analyze the extracted data from our business & 3.26 & Very High \\
$\begin{array}{l}\text { applications systems. } \\
\text { Gives feedback and inputs on how to efficiently use data. }\end{array}$ & 3.31 & Very High \\
$\begin{array}{l}\text { Uses data to back-up his report presentation to the management } \\
\text { commitee. }\end{array}$ & 3.47 & Very High \\
$\begin{array}{l}\text { Recommends improvements on how to use data from our business } \\
\text { applications systems. }\end{array}$ & 3.36 & Very High
\end{tabular}




\begin{tabular}{ccc} 
GENERAL ASSESSMENT & $\mathbf{3 . 3 6}$ & VERY HIGH \\
\hline Legend: $3.25-4.00$ Very High, $1.75-2.49$ Low, $2.5-3.24$ High, $1.00-1.74$ Very Low
\end{tabular}

Table 2.1 shows the Level of Skills of Company Managers in the use of data analytics in the Decision-Making Process as assessed by the Employees in terms of Forecasting and Planning. The general assessment was 3.36, which was verbally interpreted as "VERY HIGH". The indicator "Uses data to back-up his report presentation to the management committee" has the highest computed mean of 3.47, which was verbally interpreted as Very High, while the indicator "Teaches me on how to analyze the extracted data from our business applications systems" has the least computed mean of 3.26 and was verbally interpreted as Very High.

Overall, Company Managers have a very high level of Skills in Forecasting and Planning in the use of data analytics in the Decision-Making Process. All indicators got a very high result which implies that they have a very high level of skills at using data in the preparation and presentation of their reports. Company Managers were able to manifest as well their high level of skills by teaching their staff how to use and analyze data.

According to Bowne-Anderson (2018) the ability to understand and communicate about data is an increasingly important skill for the 21st-century citizen, for three reasons. First, data science and AI are affecting many industries globally, from healthcare and government to agriculture and finance. Second, much of the news is reported through the lenses of data and predictive models. And third, so much of our personal data is being used to define how we interact with the world. Scuoler (2020) mentioned in his article in the Institute of Business Forecasting and Planning (IBF) that business forecasting and predictive analytics are merging to leverage Big Data as a growth driver.

\subsection{Employee Learning and Development}

Table 2.2 shows the Level of Skills of Company Managers in the use of data analytics in the Decision-Making Process as assessed by the Employees in terms of Employee Learning and Development. The general assessment was 3.21, which was verbally interpreted as "HIGH". The indicator "Gives feedback and inputs on how to efficiently use data when it comes to assessing my personal learning and development plan" has the highest computed mean of 3.26, which was verbally interpreted as Very High, while the indicator "Teaches me on how to analyze the extracted data from our business applications systems when it comes to assessing my personal learning and development plan" has the least computed mean of 3.16 and was verbally interpreted as High.

Table 2.2

Level of Skills of Company Managers in the Use of Data Analytics in Decision-Making Process in terms of Employee Learning and Development

\begin{tabular}{|c|c|c|}
\hline My manager... & $\bar{X}$ & VI \\
\hline Uses data when it comes to assessing my learning journey. & 3.22 & High \\
\hline $\begin{array}{l}\text { Uses data when it comes to assessing my development and training } \\
\text { needs. }\end{array}$ & 3.19 & High \\
\hline $\begin{array}{l}\text { Teaches me on how to analyze the extracted data from our business } \\
\text { applications systems when it comes to assessing my personal } \\
\text { learning and development plan. }\end{array}$ & 3.16 & High \\
\hline $\begin{array}{l}\text { Gives feedback and inputs on how to efficiently use data when it } \\
\text { comes to assessing my personal learning and development plan. }\end{array}$ & 3.26 & Very High \\
\hline GENERAL ASSESSMENT & 3.21 & HIGH \\
\hline
\end{tabular}

Overall, it can be concluded that Company Managers have a high level of Skills in Employee Learning and Development in the use of data analytics in the Decision-Making Process. They have a very high level of skills at giving feedback and inputs on how to efficiently use data when it comes to assessing their employee's learning and development plan, while the ability to teach their staff how to analyze the extracted data from their system so they can assess their learning and development plan got the lowest computed mean, this explained why the indicator on using data when it comes to assessing their staff's development and training needs also got a low computed mean.

Chandran (2019) mentioned in the article that there are frameworks to enable measuring learning effectiveness, the most notable being the Kirkpatrick's Model. However, Chandran (2019) said that where organizations run into obstacles in leveraging these frameworks is the lack of real tools to put the framework to use. According to Chandran (2019) at each level of the Kirkpatrick Model, the first step would be to collect data, which in itself is a difficult task for beyond Level 2 for several organizations. Chandran (2019) also mentioned that as per a State of the ROI of Learning survey report by Udemy, most companies still rely on metrics at Level 1 of the Kirkpatrick Model. The majority of companies were measuring training satisfaction and completion rates. The bigger challenge however according to Chandran (2019) is that even with the availability of data, how does one go about analyzing the mass of information and generating valuable insights and enabling decisions is the big question. Chandran (2019) said that this is where Data Mining and Analytics come into picture.

\subsection{Setting Up of Key Performance Indicators}


Table 2.3

Level of Skills of Company Managers in the Use of Data Analytics in Decision-Making Process in terms of Setting Up of Key Performance Indicators

\begin{tabular}{lcc}
\hline My manager... & $\overline{\boldsymbol{X}}$ & VI \\
\hline $\begin{array}{l}\text { Uses data from our system when it comes to setting up the team's } \\
\text { KPI. }\end{array}$ & 3.35 & Very High \\
$\begin{array}{l}\text { Teaches me on how to analyze the extracted data from our business } \\
\text { applications systems when it comes to planning my individual KPI. }\end{array}$ & 3.25 & Very High \\
$\begin{array}{l}\text { Gives feedback and inputs on how to efficiently use data when it } \\
\text { comes to planning and designing my individual KP }\end{array}$ & 3.30 & Very High \\
$\begin{array}{l}\text { Uses data to evaluate operational metrics for her team's performance } \\
\text { indicator. }\end{array}$ & 3.32 & Very High \\
\hline GENERAL ASSESSMENT & $\mathbf{3 . 3 0}$ & VERY \\
& HIGH \\
\hline
\end{tabular}

Legend: 3.25 - 4.00 Very High, $1.75-2.49$ Low, $2.5-3.24$ High, 1.00 - 1.74 Very Low

Table 2.3 shows the Level of Skills of Company Managers in the use of data analytics in the Decision-Making Process as assessed by the Employees in terms of Setting Up of Key Performance Indicators. The general assessment was 3.30, which was verbally interpreted as "VERY HIGH". The indicator "Uses data from our system when it comes to setting up the team's KPI" has the highest computed mean of 3.35, which was verbally interpreted as Very High, while the indicator "Uses data to evaluate operational metrics for her team's performance indicator" has the least computed mean of 3.32 and was verbally interpreted as Very High.

Overall, it may be said that Company Managers have a very high level of Skills in Setting Up Key Performance Indicators in the use of data analytics in the Decision-Making Process. This was implied as all indicators got a very high result. This proved that Company Managers have a very high level of skills at using data from their system when it comes to setting up their team's KPI, and they are also able to teach their staff how to analyze and evaluate the data result of their KPI.

Durcevic (2020) said that using data in today's businesses is crucial to evaluate success and gather insights needed for a sustainable company. Identifying what is working and what is not is one of the invaluable management practices that can decrease costs, determine the progress a business is making, and compare it to organizational goals. Moreover, data according to Malhorata (2019) is a number or text that describes a property of a subject. This subject is what we are interested in understanding in more detail. This may be a place, a thing, a sales order, a customer, and so on. Measures for many people will use metrics and measures interchangeably, but they are not synonyms. While a measure is a representation of a property at a point in time, a metric is a collection of standardized measurements. This may be derived or calculated using a simple collection of measures. Performance indicator, according to Malhorata (2019) is another of those misunderstood and often overlooked values in the story of your data.

\subsection{Process Improvement}

Table 2.4

Level of Skills of Company Managers in the Use of Data Analytics in Decision-Making Process in terms of Process Improvement

\begin{tabular}{lcc}
\hline My manager... & $\overline{\boldsymbol{X}}$ & VI \\
\hline $\begin{array}{l}\text { Uses data from the system to analyze process gaps in our } \\
\text { department. }\end{array}$ & 3.33 & Very High \\
$\begin{array}{l}\text { Uses data to optimize her department's processes. } \\
\text { Uses data to improve her department's processes. }\end{array}$ & 3.35 & Very High \\
$\begin{array}{l}\text { Teaches me on how to use data when it comes to evaluating any } \\
\text { process improvement in our department. }\end{array}$ & 3.37 & Very High \\
$\begin{array}{l}\text { Demonstrates on how to use data in analyzing process improvement } \\
\text { in our department. }\end{array}$ & 3.28 & Very High \\
\multicolumn{1}{c}{ GENERAL ASSESSMENT } & $\mathbf{3 . 3 3}$ & Very High \\
\hline
\end{tabular}

Legend: 3.25 - 4.00 Very High, 1.75 - 2.49 Low, 2.5 - 3.24 High, 1.00 - 1.74 Very Low

Table 2.4 shows the Level of Skills of Company Managers in the use of data analytics in the Decision-Making Process as assessed by the Employees in terms of Process Improvement. The general assessment was 3.33, which was verbally interpreted as "VERY HIGH". The indicator "Uses data to improve her department's processes" has the highest computed mean of 3.37, which was verbally interpreted as Very High, while the indicator "Teaches me on how to use data when it comes to evaluating any process improvement in our department" has the least computed mean of 3.28 and was verbally interpreted as Very High.

It can be summarized that Company Managers have a very high level of Skills in Process Improvement in the use of data analytics in the Decision-Making Process. All indicators got a very high result which implies that they have a very high level of skills 
at using and teaching data to improve their departments' processes. They can demonstrate to their staff how to use data in analyzing process improvement.

According to Peco (2018) successful data-driven companies embrace and implement continuous improvement activities to enhance results, providing a structured approach for business improvement projects. Likewise, Marr (2017) stated that using data, it is possible to optimize almost every aspect of how you can run a business. Marr (2017) said that data plays a hugely important role in modern manufacturing processes as data and analytics can, for example, be used for quality control, helping to identify faults in products before they hit the market. Furthermore, Marr (2017) deduced that data can help eliminate waste and drive continuous improvement processes. And it can even help increase product yield.

Problem Number 3. Is there any significant relationship between the level of knowledge and skills in the use of data analytics in the decision-making process of Company Managers?

The table below provides findings on the problem provided above.

As shown in Table 3, the $\mathrm{r}$ values of all the variables were interpreted as with moderately high positive to high positive correlation as to correlate level of knowledge and skills in the use of data analytics in the decision-making process of Company Managers, and the computed probability values were lesser than the level of significant $(\mathrm{P}<0.05)$; thus, the null hypothesis is rejected. The result shows that there is significant relationship between the dependent and independent variables.

Table 3

Test of Significant Relationship Between the Level of Knowledge and Skills in the Use of Data Analytics in the Decision-making process of Company Managers

\begin{tabular}{|c|c|c|c|c|c|}
\hline $\begin{array}{c}\text { Level of } \\
\text { Knowledge }\end{array}$ & Level of Skills & $r$ value & $P$ value & Remarks & Decision \\
\hline \multirow{4}{*}{$\begin{array}{l}\text { Knowledge in } \\
\text { Forecasting and } \\
\text { Planning }\end{array}$} & $\begin{array}{c}\text { Skills in } \\
\text { Forecasting and } \\
\text { Planning }\end{array}$ & $.784 * *$ & .000 & Significant & Reject $\mathrm{H}_{\mathrm{o}}$ \\
\hline & $\begin{array}{c}\text { Skills in Employee } \\
\text { Learning and } \\
\text { Development }\end{array}$ & $.797 * *$ & .000 & Significant & Reject $\mathrm{H}_{\mathrm{o}}$ \\
\hline & $\begin{array}{c}\text { Skills in Setting Up } \\
\text { of Key } \\
\text { Performance } \\
\text { Indicators }\end{array}$ & $.715^{* *}$ & .000 & Significant & Reject $\mathrm{H}_{\mathrm{o}}$ \\
\hline & $\begin{array}{l}\text { Skills in Process } \\
\text { Improvement }\end{array}$ & $.730 * *$ & .000 & Significant & Reject $\mathrm{H}_{\mathrm{o}}$ \\
\hline \multirow{4}{*}{$\begin{array}{l}\text { Knowledge in } \\
\text { Employee } \\
\text { Learning and } \\
\text { Development }\end{array}$} & $\begin{array}{l}\text { Skills in } \\
\text { Forecasting and } \\
\text { Planning }\end{array}$ & $.729 * *$ & .000 & Significant & Reject $\mathrm{H}_{\mathrm{o}}$ \\
\hline & $\begin{array}{c}\text { Skills in Employee } \\
\text { Learning and } \\
\text { Development }\end{array}$ & $.860 * *$ & .000 & Significant & Reject $\mathrm{H}_{\mathrm{o}}$ \\
\hline & $\begin{array}{c}\text { Skills in Setting Up } \\
\text { of Key } \\
\text { Performance } \\
\text { Indicators }\end{array}$ & $.758 * *$ & .000 & Significant & Reject $\mathrm{H}_{\mathrm{o}}$ \\
\hline & $\begin{array}{l}\text { Skills in Process } \\
\text { Improvement }\end{array}$ & $.707 * *$ & .000 & Significant & Reject $\mathrm{H}_{\mathrm{o}}$ \\
\hline \multirow{4}{*}{$\begin{array}{l}\text { Knowledge in } \\
\text { Setting Up of Key } \\
\text { Performance } \\
\text { Indicators }\end{array}$} & $\begin{array}{l}\text { Skills in } \\
\text { Forecasting and } \\
\text { Planning }\end{array}$ & $.830 * *$ & .000 & Significant & Reject $\mathrm{H}_{\mathrm{o}}$ \\
\hline & $\begin{array}{c}\text { Skills in Employee } \\
\text { Learning and } \\
\text { Development }\end{array}$ & $.734 * *$ & .000 & Significant & Reject $\mathrm{H}_{\mathrm{o}}$ \\
\hline & $\begin{array}{c}\text { Skills in Setting Up } \\
\text { of Key } \\
\text { Performance } \\
\text { Indicators }\end{array}$ & $.786 * *$ & .000 & Significant & Reject $\mathrm{H}_{\mathrm{o}}$ \\
\hline & $\begin{array}{l}\text { Skills in Process } \\
\text { Improvement }\end{array}$ & $.756^{* *}$ & .000 & Significant & Reject $\mathrm{H}_{\mathrm{o}}$ \\
\hline
\end{tabular}




\begin{tabular}{|c|c|c|c|c|c|}
\hline \multirow{4}{*}{$\begin{array}{l}\text { Knowledge in } \\
\text { Process } \\
\text { Improvement }\end{array}$} & $\begin{array}{l}\text { Skills in } \\
\text { Forecasting and } \\
\text { Planning }\end{array}$ & $.884 * *$ & .000 & Significant & Reject $\mathrm{H}_{\mathrm{o}}$ \\
\hline & $\begin{array}{c}\text { Skills in Employee } \\
\text { Learning and } \\
\text { Development }\end{array}$ & $.795^{* *}$ & .000 & Significant & Reject $\mathrm{H}_{\mathrm{o}}$ \\
\hline & $\begin{array}{c}\text { Skills in Setting Up } \\
\text { of Key } \\
\text { Performance } \\
\text { Indicators }\end{array}$ & $.834 * *$ & .000 & Significant & Reject $\mathrm{H}_{\mathrm{o}}$ \\
\hline & $\begin{array}{l}\text { Skills in Process } \\
\text { Improvement }\end{array}$ & $.876^{* *}$ & .000 & Significant & Reject $\mathrm{H}_{\mathrm{o}}$ \\
\hline
\end{tabular}

Findings mean that the higher the level of knowledge, the higher the level of skills of Company Managers in the use of Data Analytics in the Decision-Making Process.

Schlenker (2020) via medium.com, stated that managers need to invest in data science and that managers wishing to develop their analytical skills and consequently their value to their business need to understand digital technologies influence organizational skills, processes, and networks. The end goal of Data Science isn't to introduce artificial intelligence, but to improve how people make decisions. According to Stobierski (2019) there are benefits to the organizational leaders if they opted for data-driven decision-making. Stobierski (2019) said that leaders will be able to make more confident decisions once they begin to collecting and analyzing data, they will likely find that it's easier to reach a confident decision about virtually any business challenge, whether you're deciding to launch or discontinue a product, adjust your marketing message, branch into a new market, or something else entirely. Another benefit according to Stobierski (2019) is that leaders will become more proactive and can help them realize cost savings.

Problem Number 4. What development program can be proposed to improve the knowledge and skills of Company Managers in the use of data analytics in the decision-making process?

As an output, a Development Program is proposed to improve the knowledge and skills of Company Managers in the use of Data Analytics in the Decision-Making process. The following Table 4 presents the proposed development program.

Table 4

The Proposed Development Program

\begin{tabular}{|c|c|c|c|c|c|c|}
\hline $\begin{array}{c}\text { KEY } \\
\text { RESULT } \\
\text { AREA } \\
\end{array}$ & OBJECTIVES & $\begin{array}{l}\text { STRATEGIES/ } \\
\text { ACTIVITIES }\end{array}$ & $\begin{array}{c}\text { TIME } \\
\text { FRAME }\end{array}$ & $\begin{array}{l}\text { PERSONS } \\
\text { INVOLVED }\end{array}$ & $\begin{array}{l}\text { SOURCE } \\
\text { OF FUND }\end{array}$ & $\begin{array}{c}\text { SUCCESS } \\
\text { INDICATORS }\end{array}$ \\
\hline $\begin{array}{l}\text { Data } \\
\text { Knowledge }\end{array}$ & $\begin{array}{l}\text { Launch a data } \\
\text { literacy learning } \\
\text { program by June } \\
30,2022 \text { to } \\
\text { improve the } \\
\text { company's } \\
\text { decision-making } \\
\text { process. }\end{array}$ & $\begin{array}{l}\text { Communicate with } \\
\text { all employees } \\
\text { about the plan to } \\
\text { launch a data } \\
\text { literacy program. } \\
\text { Explain the } \\
\text { objective of the } \\
\text { program. } \\
\text { Conduct a data } \\
\text { literacy assessment } \\
\text { to reveal the gaps } \\
\text { of the employees' } \\
\text { data knowledge } \\
\text { and skills. } \\
\text { Include in the } \\
\text { annual (2022) } \\
\text { Employee } \\
\text { Learning and } \\
\text { Development } \\
\text { budget the hiring } \\
\text { of a Data Analytics } \\
\text { Expert to help with } \\
\text { the development of } \\
\text { a data literacy } \\
\text { training program. }\end{array}$ & $\begin{array}{l}\text { Jan. 15, } \\
2022 \\
\text { Feb. 15, } \\
2022\end{array}$ & $\begin{array}{l}\text { Management } \\
\text { Committee, } \\
\text { Employees } \\
\text { Employees }\end{array}$ & $\begin{array}{l}\text { Company } \\
\text { Approved } \\
2022 \text { Budget }\end{array}$ & $\begin{array}{l}100 \% \text { of the } \\
\text { Company's } \\
\text { data on } \\
\text { financial } \\
\text { reports are } \\
\text { extracted } \\
\text { from the } \\
\text { business } \\
\text { applications } \\
\text { systems. } \\
\text { KPI } \\
\text { Dashboards } \\
\text { are in placed } \\
\text { by December } \\
31,2022 \text {. }\end{array}$ \\
\hline
\end{tabular}




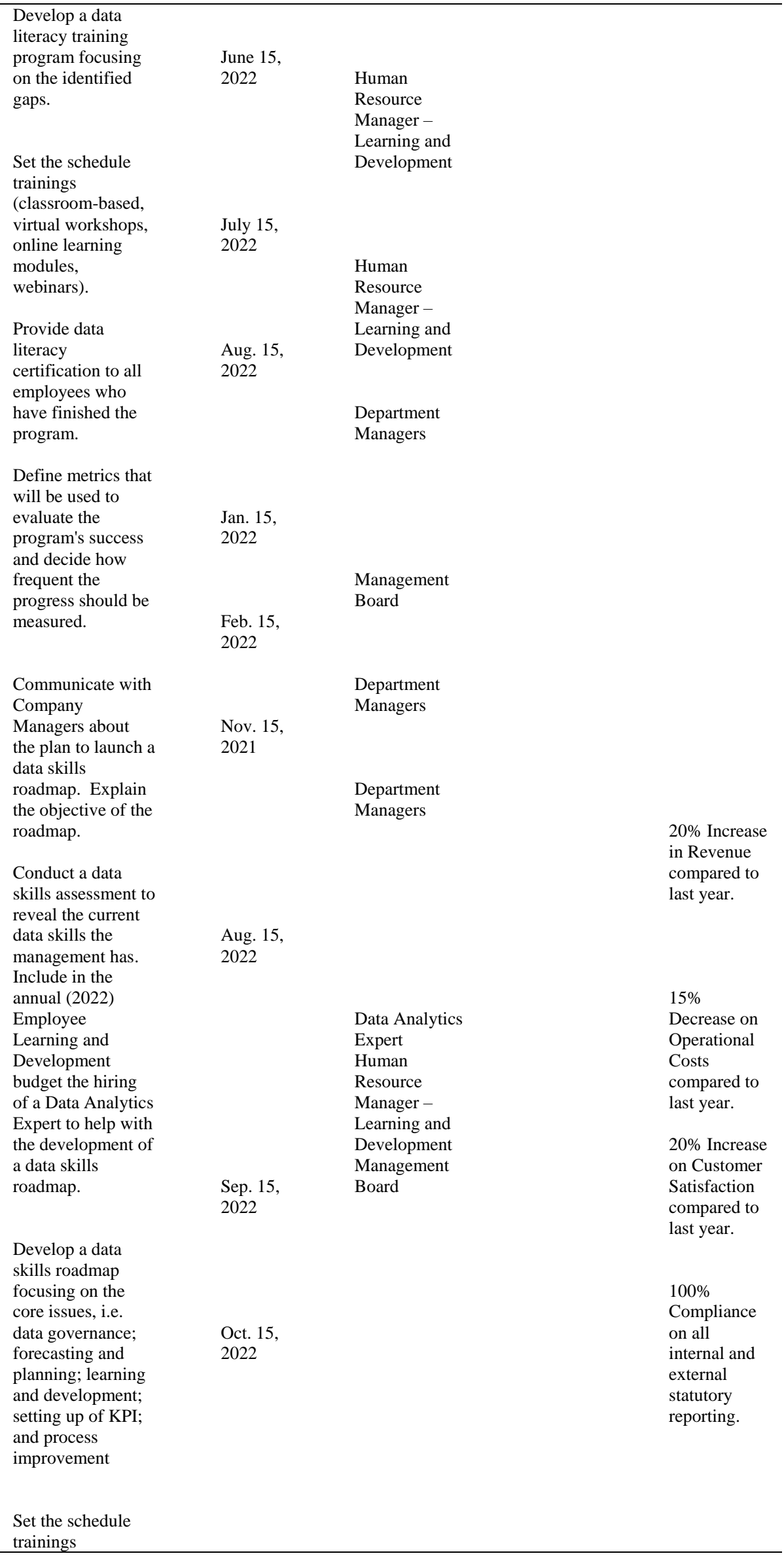

\footnotetext{
Launch a data skills roadmap by September 30 , 2022 to improve the company's data management to support a better decision-making process.
}

$20 \%$ Increase 


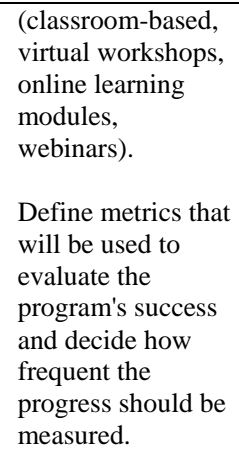

\section{CONCLUSION}

1. That relying on data in the preparation of reports such as budgets and encouraging employees to use data analytics are tangible proofs that Company Managers have a good level of knowledge in the use of data analytics in the decision-making process. Relying on data when it comes to assessing their employees' development and training needs and encouraging their employees to use data to assess their own learning journey are great factors for Company Managers in having a good level of knowledge in the use of data analytics in the decision-making process. Encouraging their employees to use data when it comes to planning their individual KPI, as well as relying on data when it comes to setting up the team's KPI are very good manifestations for Company Managers in having a very good level of knowledge in the use of data analytics in the decision-making process. Making sure that all pertinent data in improving the department's processes are available in the system and relying on data to optimize their department's processes are good indicators that Company Managers have a very good level of knowledge in the use of data analytics in the decision-making process.

2. That using data in backing-up report during presentation to the management committee, as well as in the preparation of budget are tangible proofs that Company Managers have a very good level of skills in the use of data analytics in the decision-making process. Giving feedback and inputs as well as applying data on how to efficiently use data when it comes to assessing their employees personal learning and development plan are great factors for Company Managers in having a good level of skills in the use of data analytics in the decision-making process. Using data extracted from the system when it comes to setting up the team's KPI, as well using data in evaluating operational metrics of their teams are very good indicators for Company Managers in having a very good level of skills in the use of data analytics in the decision-making process. Using data to improve improve and optimize their department's processes are a very good manifestations for Company Managers in having a very good level of knowledge in the use of data analytics in the decision-making process.

3. That the strength of association between Knowledge and Skills of the Company Managers in using Data Analytics in the Decisionmaking process is high. This reveals that familiarity with the theoretical concepts about data analytics can manifest in the ability to apply them in the workplace.

4. That the proposed Development Program is necessary to enhance the level of knowledge and skils of Company Managers in the use of data analytics in their decision-making process.

Based on the findings summarized and conclusions drawn, the following recommendations are hereby offered:

1. Companies should make an effort to stay current with new developments in the technology and techniques as the company learn to lead with data.

2. Companies should consider replacing all manual monitoring boards to digital dashboards with interactive, visual capabilities that let users explore data to find actionable insights, driven by the company's business systems applications, i.e., ERP, BI.

3. Companies regardless of size, should include data analytics as part of their business strategy. Having a clear data strategy will help the company in driving better and faster decisions. This direction should come from the top management to reduce potential resistance from employees. Company Managers should also be tasked as data ambassadors to help promote the greater use of data in events such as meetings, discussions, and evaluations. This will help show the rest of the employees that the data-driven culture is taken seriosly by the management.

4. Companies should consider launching a data literacy learning program to strengthen data knowledge among all employees to improve everyone's ability to read, work with, analyze, and communicate data. This will help empower their workforce by investing in their professional development. Moreover, companies should consider launching a data skills roadmap specifically for their Company Managers to improve the company's data management to support a better decision-making process. This is critical for the company's success in this growing digital era. The proposed development program may also be utilized by companies.

5. Future researchers may want to expand the study by considering a mixed method explanatory sequential design. This will provide a better perspective in understanding the results by having the opportunity to interview the respondents of the study. 
APPENDIX

\section{CRONBACH'S ALPHA RELIABILITY TEST}

Scale: KNOWLEDGE-FORCASTING AND PLANNING

Reliability Statistics

Cronbach's

Alpha Based on

Cronbach's

Standardized

Alpha

Items

$\mathrm{N}$ of Items

.866

.878

\section{Item-Total Statistics}

\begin{tabular}{l|r|r|r|r|r} 
& $\begin{array}{c}\text { Scale Mean if } \\
\text { Item Deleted }\end{array}$ & $\begin{array}{c}\text { Scale Variance } \\
\text { if Item Deleted }\end{array}$ & $\begin{array}{c}\text { Corrected Item- } \\
\text { Total } \\
\text { Correlation }\end{array}$ & $\begin{array}{c}\text { Squared } \\
\text { Multiple } \\
\text { Correlation }\end{array}$ & $\begin{array}{c}\text { Cronbach's } \\
\text { Alpha if Item } \\
\text { Deleted }\end{array}$ \\
\hline KFP1 & 20.80 & 9.289 & .758 & .914 & .830 \\
\hline KFP2 & 20.70 & 7.789 & .785 & .952 & .835 \\
\hline KFP3 & 20.20 & 11.956 & .488 & .856 & .868 \\
\hline KFP4 & 20.40 & 11.600 & .480 & .667 & .867 \\
\hline KFP5 & 20.40 & 10.933 & .690 & .918 & .846 \\
\hline KFP6 & 20.60 & 10.711 & .763 & .848 & .839 \\
\hline KFP7 & 20.90 & 8.989 & .724 & .807 & .837 \\
\hline
\end{tabular}

Scale: KNOWLEDGE-LEARNING AND DEVELOPMENT

\begin{tabular}{|c|c|c|c|c|c|}
\hline & & $\begin{array}{c}\text { Relia } \\
\begin{array}{c}\text { Cronbach's } \\
\text { Alpha }\end{array} \\
.970\end{array}$ & $\begin{array}{l}\text { ability Statistics } \\
\text { Cronbach's } \\
\text { Alpha Based on } \\
\text { Standardized } \\
\text { Items } \\
.973\end{array}$ & $\frac{\mathrm{N} \text { of Items }}{6}$ & \\
\hline \multicolumn{6}{|c|}{ Item-Total Statistics } \\
\hline & $\begin{array}{l}\text { Scale Mean if } \\
\text { Item Deleted }\end{array}$ & $\begin{array}{l}\text { Scale Variance } \\
\text { if Item Deleted }\end{array}$ & $\begin{array}{c}\text { Corrected Item- } \\
\text { Total } \\
\text { Correlation } \\
\end{array}$ & $\begin{array}{c}\text { Squared } \\
\text { Multiple } \\
\text { Correlation }\end{array}$ & $\begin{array}{l}\text { Cronbach's } \\
\text { Alpha if Item } \\
\text { Deleted }\end{array}$ \\
\hline KLD1 & 16.40 & 10.933 & .836 & 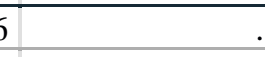 & .971 \\
\hline KLD2 & 16.50 & 10.500 & .991 & 1 & .955 \\
\hline KLD3 & 16.50 & 10.500 & .991 & 1 & .955 \\
\hline KLD4 & 16.50 & 10.500 & .991 & 1 & .955 \\
\hline KLD5 & 16.50 & 10.500 & .991 & & .955 \\
\hline KLD6 & 16.60 & 11.156 & .666 & & .991 \\
\hline
\end{tabular}

\section{Scale: KNOWLEDGE-KEY PERFORMANCE INDICATORS}




\begin{tabular}{ll|c|c|c|c} 
& \multicolumn{5}{c}{ Reliability Statistics } \\
Cronbach's \\
\end{tabular}

\section{Scale: KNOWLEDGE-PROCESS IMPROVEMENT}

\begin{tabular}{|c|c|c|c|c|c|}
\hline & & $\begin{array}{l}\text { Cronbach's } \\
\text { Alpha } \\
\end{array}$ & $\begin{array}{l}\text { iability Statistics } \\
\text { Cronbach's } \\
\text { Alpha Based on } \\
\text { Standardized } \\
\text { Items } \\
\end{array}$ & $\mathrm{N}$ of Items & \\
\hline & & .900 & .901 & 6 & \\
\hline \multicolumn{6}{|c|}{ Item-Total Statistics } \\
\hline & $\begin{array}{l}\text { Scale Mean if } \\
\text { Item Deleted }\end{array}$ & $\begin{array}{l}\text { Scale Variance } \\
\text { if Item Deleted }\end{array}$ & \begin{tabular}{|c} 
Corrected Item- \\
Total \\
Correlation
\end{tabular} & $\begin{array}{c}\text { Squared } \\
\text { Multiple } \\
\text { Correlation }\end{array}$ & $\begin{array}{l}\text { Cronbach's } \\
\text { Alpha if Item } \\
\text { Deleted }\end{array}$ \\
\hline KPI1 & 17.90 & 5.878 & .586 & & .903 \\
\hline KPI2 & 17.80 & 5.511 & .823 & 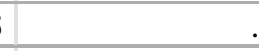 & .872 \\
\hline KPI3 & 17.70 & 6.456 & .456 & 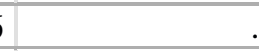 & .917 \\
\hline KPI4 & 17.90 & 5.211 & .905 & 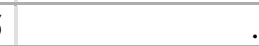 & .858 \\
\hline KPI5 & 18.20 & 4.844 & .778 & 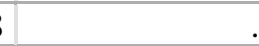 & .877 \\
\hline KPI6 & 18.00 & 4.444 & .894 & 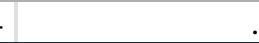 & .856 \\
\hline
\end{tabular}

\section{Scale: SKILL-FORCASTING AND PLANNING}

This publication is licensed under Creative Commons Attribution CC BY. 


\begin{tabular}{|c|c|c|}
\hline \multicolumn{3}{|c|}{ Reliability Statistics } \\
\hline & Cronbach's & \\
\hline & Alpha Based on & \\
\hline Cronbach's & Standardized & \\
\hline Alpha & Items & $\mathrm{N}$ of Items \\
\hline .911 & .926 & 6 \\
\hline
\end{tabular}

\begin{tabular}{|c|c|c|c|c|c|}
\hline \multicolumn{6}{|c|}{ Item-Total Statistics } \\
\hline & $\begin{array}{l}\text { Scale Mean if } \\
\text { Item Deleted }\end{array}$ & $\begin{array}{l}\text { Scale Variance } \\
\text { if Item Deleted }\end{array}$ & $\begin{array}{c}\text { Corrected Item- } \\
\text { Total } \\
\text { Correlation }\end{array}$ & $\begin{array}{c}\text { Squared } \\
\text { Multiple } \\
\text { Correlation }\end{array}$ & $\begin{array}{l}\text { Cronbach's } \\
\text { Alpha if Item } \\
\text { Deleted }\end{array}$ \\
\hline SFP1 & 17.00 & 10.889 & .799 & & .903 \\
\hline SFP2 & 17.30 & 10.678 & 677 & & .908 \\
\hline SFP3 & 17.70 & 7.122 & .976 & & .862 \\
\hline SFP4 & 17.50 & 8.278 & .753 & & .903 \\
\hline SFP5 & 17.00 & 10.222 & .659 & & .908 \\
\hline SFP6 & 17.50 & 9.167 & .897 & & .876 \\
\hline
\end{tabular}

Scale: SKILL-LEARNING AND DEVELOPMENT

\begin{tabular}{|c|c|c|}
\hline \multirow{2}{*}{\multicolumn{3}{|c|}{ Reliability Statistics }} \\
\hline & & \\
\hline & Alnhe Roced on & \\
\hline Cronbach's & Standardized & \\
\hline Alpha & Items & $\mathrm{N}$ of Items \\
\hline .947 & .965 & 4 \\
\hline
\end{tabular}

\begin{tabular}{lr|r|r|r|r} 
& \multicolumn{5}{c}{ Item-Total Statistics } \\
& $\begin{array}{c}\text { Scale Mean if } \\
\text { Item Deleted }\end{array}$ & $\begin{array}{c}\text { Scale Variance } \\
\text { if Item Deleted }\end{array}$ & $\begin{array}{c}\text { Corrected Item- } \\
\text { Total } \\
\text { Correlation }\end{array}$ & $\begin{array}{c}\text { Squared } \\
\text { Multiple } \\
\text { Correlation }\end{array}$ & $\begin{array}{c}\text { Cronbach's } \\
\text { Alpha if Item } \\
\text { Deleted }\end{array}$ \\
\hline SLD1 & 9.90 & 3.433 & .975 &. & .913 \\
\hline SLD2 & 10.00 & 3.111 & .840 &. & .943 \\
\hline SLD3 & 10.10 & 2.767 & .830 &. & .964 \\
\hline SLD4 & 9.90 & 3.433 & .975 &. & .913 \\
\hline
\end{tabular}

\section{Scale: SKILL-KEY PERFORMANCE INDICATORS}

This publication is licensed under Creative Commons Attribution CC BY. 


\begin{tabular}{c|c|c}
\multicolumn{3}{c}{ Reliability Statistics } \\
& $\begin{array}{c}\text { Cronbach's } \\
\text { Alpha Based on } \\
\text { Cronbach's } \\
\text { Alpha }\end{array}$ & $\begin{array}{c}\text { Standardized } \\
\text { Items }\end{array}$ \\
\hline .871 & N of Items \\
\hline
\end{tabular}

\begin{tabular}{|c|c|c|c|c|c|}
\hline \multicolumn{6}{|c|}{ Item-Total Statistics } \\
\hline & $\begin{array}{l}\text { Scale Mean if } \\
\text { Item Deleted }\end{array}$ & $\begin{array}{l}\text { Scale Variance } \\
\text { if Item Deleted }\end{array}$ & $\begin{array}{c}\text { Corrected Item- } \\
\text { Total } \\
\text { Correlation } \\
\end{array}$ & $\begin{array}{c}\text { Squared } \\
\text { Multiple } \\
\text { Correlation } \\
\end{array}$ & $\begin{array}{l}\text { Cronbach's } \\
\text { Alpha if Item } \\
\text { Deleted }\end{array}$ \\
\hline SKPI 1 & 10.40 & 2.267 & .800 & .881 & .809 \\
\hline SKPI2 & 10.50 & 1.833 & .754 & .852 & .836 \\
\hline SKPI3 & 10.60 & 2.267 & .800 & .815 & .809 \\
\hline SKPI4 & 10.50 & 2.500 & .600 & .733 & .880 \\
\hline
\end{tabular}

\section{Scale: SKILL-PROCESS IMPROVEMENT}

\begin{tabular}{r|r|r}
\multicolumn{3}{c}{ Reliability Statistics } \\
Cronbach's \\
Alpha Based on \\
$\begin{array}{c}\text { Cronbach's } \\
\text { Alpha }\end{array}$ & $\begin{array}{c}\text { Standardized } \\
\text { Items }\end{array}$ & N of Items \\
\hline .962 & .970 & 5 \\
\hline
\end{tabular}

\begin{tabular}{|c|c|c|c|c|c|}
\hline \multicolumn{6}{|c|}{ Item-Total Statistics } \\
\hline & $\begin{array}{l}\text { Scale Mean if } \\
\text { Item Deleted }\end{array}$ & $\begin{array}{l}\text { Scale Variance } \\
\text { if Item Deleted }\end{array}$ & $\begin{array}{c}\text { Corrected Item- } \\
\text { Total } \\
\text { Correlation } \\
\end{array}$ & $\begin{array}{c}\text { Squared } \\
\text { Multiple } \\
\text { Correlation } \\
\end{array}$ & $\begin{array}{c}\text { Cronbach's } \\
\text { Alpha if Item } \\
\text { Deleted } \\
\end{array}$ \\
\hline SPI1 & 13.30 & 6.456 & .915 & & .955 \\
\hline SPI2 & 13.40 & 5.600 & .960 & & .942 \\
\hline SPI3 & 13.30 & 5.789 & .845 & & .962 \\
\hline SPI4 & 13.50 & 5.167 & .930 & & .952 \\
\hline SPI5 & 13.30 & 6.456 & .915 & & .955 \\
\hline
\end{tabular}

\section{ACKNOWLEDGMENT}

This study would not have been made possible without the help and guidance of the following individuals. The researcher would like to express her sincere gratitude to: 

this study;

Dr. Cristina A. San Jose, her adviser, for her assistance and dedicated involvement in every step throughout the process of

Dr. Ma. Lorena M. Tagala, the Dean of the School of Graduate Studies of LCBA, for providing the necessary support and permission to conduct this study;

Prof. Melchor A. Villapando, the Statistician of LCBA, for the statistical treatment and assistance to the study;

Dr. Fernando T. Pendon III, and Dr. Antonio R. Yango, her panelists, for critiquing and giving corrections and suggestion for the improvement of the study;

Company Heads and Managers, for allowing her to conduct the study in their respective companies, and for their gracious effort in cascading the survey to their colleagues and communicating to their respective teams;

The Respondents, for lending their time in answering the survey despite their busy work schedule;

The Almighty God, for the good health and well-being that were necessary to complete this study; and

Finally, her profound gratitude to her family, for providing unfailing support and continuous encouragement throughout the study. This accomplishment would not have been possible without them.

\section{REFERENCES}

[1] Alcala, L. (2017). 4 Ways to Improve Your Data-Driven Decision-Making. Retrieved from: https://www.cmswire.com/analytics/4-ways-to-improve-your-datadriven-decision-making/

[2] Castor, R. (2020). The Illusions of Making Data-Driven Decisions. Retrieved from: https://towardsdatascience.com/the-illusion-of-making-data-driven-decisionsbf54a2e594c4

[3] Chandler, J. (2017). Descriptive Decision Theory. Retrieved from: https://plato.stanford.edu/archives/win2017/entries/decision-theory-descriptive

[4] Chandran, P. (2019). Benefits of Applying Data Analytics to Learning \& Development. Retrieved from: https://www.linkedin.com/pulse/benefits-applying-dataanalytics-learning-development-preeta-chandran/

[5] Chase, C. (2019). Practical approaches to new product forecasting using structured and unstructured data. Retrieved from: https://blogs.sas.com/content/sascom/2019/02/19/practical-approaches-to-new-product-forecasting-using-structured-and-unstructured-data/

[6] Cook, I. (2017). You Need Analytics to Know If Your L\&D Program Is Making A Difference. Retrieved from: https://www.tlnt.com/you-need-analytics-to-knowif-your-ld-program-is-making-a-difference/

[7] Delen, D. (2019, https://books.google.com.ph/books?id=Qh24DwAAQBAJ\&pg=PT13\&source=gbs_toc_r\&cad=3\#v=onepage\&q\&f=false

[8] Durcevic, S. (2019). Why Data Driven Decision Making is Your Path To Business Success. Retrieved from: https://www.datapine.com/blog/data-driven-decisionmaking-in-businesses/

[9] Durcevic, S. (2020). Take Advantage of Operational Metrics \& KPI Examples - A Comprehensive Guide. Retrieved from: https://www.datapine.com/blog/operational-metrics-and-kpi-examples/

[10] Gilliland, M. (2020). Do the Principles of Analytics Apply to Forecasting? Retrieved from: https://blogs.sas.com/content/forecasting/2020/06/16/do-the-principlesof-analytics-apply-to-forecasting/

[11] Gottlied, J. \& Weinberg, A. (2019). Catch them if you can: How leaders in data and analytics have pulled ahead. Retrieved from: https://www.mckinsey.com/business-functions/mckinsey-analytics/our-insights/catch-them-if-you-can-how-leaders-in-data-and-analytics-have-pulled-ahead

[12] Hallo, L., Nguyen T., Gorod, A., \& Tran, P. (2020). Effectiveness of Leadership Decision-Making in Complex Systems. Retrieved from: https://www.mdpi.com/2079-8954/8/1/5/htm

[13] Bowne-Anderson (2018). Your Data Literacy Depends on Understanding the Types of Data and How They're Captured. Retrieved from: https://files.transtutors.com/cdn/uploadassignments/5517328_2_week-1-reading-your-data-literacy.pdf

[14] Ismail, N. (2017). Using data analytics to improve business processes and reduce waste. Retrieved from: https://www.information-age.com/using-data-analyticsimprove-business-process-waste-123464115/

[15] Jackson, S., Kleitman, S.,Howie, P., \& Stankov, L. (2016). Cognitive Abilities, Monitoring Confidence, and Control Thresholds Explain Individual Differences in Heuristics and Biases. Retrieved from: https://www.frontiersin.org/articles/10.3389/fpsyg.2016.01559/full.

[16] Kaluba, K. (2020). How a data analytics strategy supports resiliency in uncertain times. Retrieved from: https://blogs.sas.com/content/datamanagement/2020/06/18/data-analytics-strategy-resiliency/

[17] Kohl, O. (2019). An End to KPI Misdirection: Aligning Data to Strategy. Retrieved from: https://www.rtinsights.com/the-case-for-orchestrated-kpis/

[18] Malhorata, B. (2019). From Data to KPI - The Story of a Number. Retrieved from: https://wyn.grapecity.com/blogs/from-data-to-kpi-the-story-of-a-number

[19] Malhorata, S. (2018). 4 styles of decision-making: A leader's guide. Retrieved from: https://enterprisersproject.com/article/2018/7/4-styles-decision-makingleaders-guide

[20] Marr, B. (2017). Data Strategy: How To Profit From A World of Big Data, Analytics And The Internet of Things. Retrieved from: https://www.academia.edu/36846617/Sanet_cd_Data_Strategy

[21] Omer, A. (2019). The importance of Learning Analytics in Learning and Development. Retrieved from: https://elearningindustry.com/learning-analytics-benefitsld

[22] Onley, D. (2019). How Leaders Can Make Better Decisions. Retrieved from: https://www.shrm.org/hr-today/news/hr-magazine/fall2019/pages/how-leaders-canmake-better-decisions.aspx

[23] Peco, M. (2018). Continuous Business Process Improvement Depends on Data Governance. Retrieved from: https://erwin.com/blog/data-governance-continuousimprovement/

[24] Pelland, D. (2017). Big Data Needs Advanced Analytics to Forecast the Financial Future. Retrieved from: https://www.financialexecutives.org/FEI-Daily/July2017/optimizing-business-planning-advanced-analytics.aspx

[25] Roy, E. (2017, July 27). 4 Types of Data Analytics To Improve Decision-Making. Retrieved from: https://www.knowledgehut.com/blog/big-data/4-types-of-dataanalytics-to-improve-decision-making

This publication is licensed under Creative Commons Attribution CC BY.

http://dx.doi.org/10.29322/IJSRP.11.08.2021.p11614

WwW.ijsrp.org 
[26] Shacklett, M. (2020). 4 ways to use data to make better business decisions. Retrieved from: https://www.techrepublic.com/article/4-ways-to-use-data-to-makebetter-business-decisions/

[27] Schenker,L. (2020). What Managers Should Know About Data Science. Retrieved from: https://medium.com/swlh/what-managers-should-know-about-datascience-736bdab7c8ae

[28] Scuoler,A. (2020). How Business Forecasting \& Predictive Analytics Are Merging. Retrieved from: https://demand-planning.com/2020/12/07/how-businessforecasting-predictive-analytics-are-merging/

[29] Solanki, A. (2018). What hides in your data - potential to change the business paradigm. Retrieved from: https://www.softwebsolutions.com/resources/leveragedata-analytics-for-business.html

[30] Stobierski, T. (2019). The Advantages of Data-Driven Decision-Making. Retrieved from: https://online.hbs.edu/blog/post/data-driven-decision-making

[31] Swabey, P. (2018). From data overload to effective decision-making. Retrieved from: https://eiuperspectives.economist.com/strategy-leadership/data-overloadeffective-decision-making-0/article/data-overload-effective-decision-making

[32] Turnali, K. (2019). Better Business Decisions Start With Better-Informed Leaders. Retrieved from: https://blogs.sap.com/2017/08/19/better-business-decisionsstart-with-better-informed-leaders/

[33] Vigliarolo, B. (2020). Businesses understand the value of big data, but employees aren't being trained to use it. Retrieved from: https://www.techrepublic.com/article/businesses-understand-the-value-of-big-data-but-employees-arent-being-trained-to-use-it/

[34] Wassmer, S. (2020). Reasons why data-driven decision-making can go wrong: Analysis Paralysis. Retrieved from: https://www.appnovation.com/blog/2020-05reasons-why-data-driven-decision-making-can-go-wrong-analysis-paralysis

[35] Wishart, J. (2018). Leadership and Levels and Styles of Decision Making. Retrieved from: https://www.rhythmsystems.com/blog/leadership-and-levels-and-stylesof-decision-making

[36] Zettelmeyer, F. (2015). May 1 A Leader's Guide to Data Analytics. Retrieved from: https://insight.kellogg.northwestern.edu/article/a-leaders-guide-to-dataanalytics

\section{AUTHORS}

First Author - Maricar V. Maniquis, MBA, king.maniquis@gmail.com.

Correspondence Author - Maricar V. Maniquis, MBA, king.maniquis@gmail.com., +639178236224 